\title{
Tel uw zegeningen
}

Citation for published version (APA):

Kuijten, R. H. (1995). Tel uw zegeningen. Maastricht University. https://doi.org/10.26481/spe.19951201rk

Document status and date:

Published: 01/12/1995

DOI:

10.26481/spe.19951201rk

Document Version:

Publisher's PDF, also known as Version of record

\section{Please check the document version of this publication:}

- A submitted manuscript is the version of the article upon submission and before peer-review. There can be important differences between the submitted version and the official published version of record.

People interested in the research are advised to contact the author for the final version of the publication, or visit the DOI to the publisher's website.

- The final author version and the galley proof are versions of the publication after peer review.

- The final published version features the final layout of the paper including the volume, issue and page numbers.

Link to publication

\footnotetext{
General rights rights.

- You may freely distribute the URL identifying the publication in the public portal. please follow below link for the End User Agreement:

www.umlib.nl/taverne-license

Take down policy

If you believe that this document breaches copyright please contact us at:

repository@maastrichtuniversity.nl

providing details and we will investigate your claim.
}

Copyright and moral rights for the publications made accessible in the public portal are retained by the authors and/or other copyright owners and it is a condition of accessing publications that users recognise and abide by the legal requirements associated with these

- Users may download and print one copy of any publication from the public portal for the purpose of private study or research.

- You may not further distribute the material or use it for any profit-making activity or commercial gain

If the publication is distributed under the terms of Article $25 \mathrm{fa}$ of the Dutch Copyright Act, indicated by the "Taverne" license above, 
Universiteitsblbliotheek

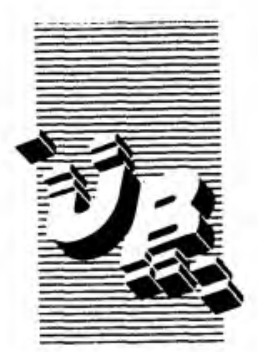

De uitleentermijn verstrijkt op:

\section{Q2 4667996}

Rijksuniversiteit Limburg

Postbus 616

6200 MD Maastricht

Gelieve deze publicatie tijdig te retourneren of (telefonisch) verlenging van de uitleentermijn aan te vragen.

UNIVERSITEITSBIBLIOTHEEK RU LIMBURG

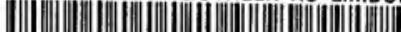




\section{Tel uw zegeningen}

Rede

in verkorte vorm uitgesproken ter

gelegenheid van het afscheid als

hoogleraar kindergeneeskunde aan de

Rijksuniversiteit Limburg

op 1 december 1995

door

Prof. Dr. R.H. Kuijten 
143414267 Universiteitsibibliotheek Rijksuniversiteit Limourg 


\section{Mijnheer de Rector Magnificus \\ Geachte toehoorders,}

Het is met enige schroom dat ik hier voor $\mathrm{u}$ sta om een voordracht te houden die men gewoonlijk afscheidscollege noemt.

Om te beginnen is het begrip 'college geven' volgens de Maastrichtse filosofie bijna iets oneerbaars. De student loopt hier geen colleges maar wordt op andere wijze geschoold. Een verhaal van 3 kwartier door één persoon waarin dan ook nog niet geïnterrumpeerd kan worden door de toehoorder, dat is in Maastricht alleen gebruikelijk bij Dies-rede, oratie en ja, het afscheidscollege.

Verder is de doelgroep, dat bent $u$, geachte toehoorders, zeer heterogeen. Mijn Maastrichtse collegae komen niet hier om te horen hoe het in Maastricht is gegaan. Mijn vakbroeders verwachten niet de ontwikkelingen binnen de kindergeneeskunde te vernemen. $\mathrm{Zij}$ hebben immers de nota 'Kindergeneeskunde in Nederland' van de Nederlandse Vereniging voor Kindergeneeskunde 1992 bestudeerd en hebben de afscheidsrede's van de collegae van den Brande en Visser recentelijk bijgewoond of gelezen. Bovendien willen ook ouders van patiënten, familie, vrienden en kennissen graag kunnen volgen wat er wordt gezegd. Een goed college dus, dat is toegesneden op een dergelijke doelgroep, is niet te verwezenlijken. Wat u echter allen gemeenschappelijk heeft, is dat $u$ tijd heeft vrijgemaakt om naar mijn afscheid te komen en dat geeft mij de vrijheid om u gewoon dingen te vertellen die mij voor $u$ interessant lijken.

Wat is het doel van dit college, deze afscheidsrede ? Is het een grafrede, uitgesproken door de stervende zelf of een lofzang waarin alle goede daden worden opgesomd om ze aan de vergetelheid te onttrekken en om vooral duidelijk te maken waarin de spreker goed was en wat hij allemaal tot stand heeft gebracht ? Ik zal dat niet doen, trouwens ik zie een enkeling onder $u$ al denken 'dan is hij gauw klaar'.

Bij het overdenken van mijn ervaringen en het overzien van 
mijn werkzame jaren werd ik mij weer eens bewust van het grote voorrecht dat wij genieten om in deze tijd en met de huidige verworvenheden de kindergeneeskunde te beoefenen, onderzoek te mogen doen, kennis te mogen verwerven, de patiënten daarvan te laten profiteren en onze kennis en kunde over te mogen dragen aan jonge mensen, die met minstens evenveel enthousiasme maar op hun eigen wijze ons werk zullen voortzetten. 'Tel uw zegeningen', leek mij daarom een goede titel als ondertoon voor hetgeen ik $\mathrm{u}$ wil vertellen en als boodschap die ik u zou willen meegeven.

\section{Van weeshuis tot kinderafdeling}

Wanneer wij naar de geschiedenis kijken dan vonden de eerste concentraties van hulpbehoevende kinderen plaats in tehuizen voor wezen en vondelingen. De sterfte in deze weeshuizen, vooral onder de zuigelingen, was hoog. Het eerste kinderziekenhuis werd in 1802 gesticht in Parijs. Het is het nog steeds vermaarde Hôpital des Enfants Malades, dat verbonden is met het Hopital Necker, waar zowel ik als onze collega van der Meer een deel van onze subspecialistische vorming hebben genoten. In Nederland werd het eerste kinderziekenhuis in 1863 gesticht in Rotterdam, het Sophia Kinderziekenhuis, gevolgd door in 1865 het Emma Kinderziekenhuis in Amsterdam, een kinderziekenhuis in 1882 in Arnhem en in 1885 een kinderziekenhuis in Dordrecht en het Juliana Kinderziekenhuis in Den Haag. Het Wilhelmina Kinderziekenhuis in Utrecht, waar ik 18 jaar heb gewerkt, werd opgericht in 1888. Alle kinderklinieken, met namen verbonden aan het Koninklijk Huis, hebben standgehouden. Collega Heijmans in Groningen heeft dat heel goed aangevoeld, door de academische kinderkliniek in Groningen om te dopen in 'Beatrix Kinderkliniek' en aldus haar voortbestaan voor het nageslacht veilig te stellen. Voor ons in Maastricht het 'Willem-Alexander Kinder- en Jeugdcentrum'?

Ook in de Maastrichtse annalen wordt melding gemaakt van een provinciaal tehuis voor vondelingen, waarover het Burgerlijk Armbestuur tot 1824 het toezicht had. In 1820 werd de intramurale gezondheidszorg gecentraliseerd in het Calvariënbergcomplex, een voormalig klooster. In 1891 werd aldaar een volledige nieuwbouw 
betrokken. Tien jaar later werd de gedachte geopperd om kinderen, die tot dan toe waren ondergebracht op zalen bestemd voor volwassenen, op een afzonderlijke afdeling te verplegen. Voor kinderen onder de 10 jaar werd een dagverblijf van de vrouwenafdeling ingericht als verpleegzaal. Hoe het verder precies is gegaan weet $\mathrm{ik}$ niet, maar er bestaan foto's van een dichtbevolkte kinderzaal in de Calvariënberg uit 1930, terwijl een foto uit 1935 aangeeft dat er al sprake was van de mogelijkheid tot afzondering van in die tijd vooral besmettelijke patiënten.

In het ziekenhuis St. Annadal, dat in 1950 werd betrokken, was een grote kinderafdeling ingericht, die in 1956 een belangrijke plaats innam als een van de 10 poliocentra in ons land. Uit het boekje 'Annadal 19501985', waaruit het bovenstaande ook afkomstig is, citeer ik: 'In 1956 was er een ernstige polio-epidemie in Nederland en de zorg voor de poliopatiënten in Zuid-Limburg werd geconcentreerd in St. Annadal. Aangezien de meeste polio-patiënten van jeugdige leeftijd waren, werd naast de behandeling en revalidatie, bijzonder veel aandacht besteed aan de sociaal-psychologische en opvoedkundige begeleiding van de patiënten. Men streefde ernaar te voorkomen dat de kinderen tijdens hun langdurig verblijf in het ziekenhuis, zouden vervreemden van hun ouders en in hun ontwikkeling een achterstand zouden oplopen. Daarom voegde men aan het team van artsen, fysiotherapeuten en verpleegsters een onderwijzeres en een sociaal werkster toe. Aan het hoofd van het polio-centrum stond de kinderarts L.H.J. Ramaekers, die nauw samenwerkte met de orthopeed H.G.A. Naber en de neuroloog G. Padberg'.

Voorwaar reeds toen in Maastricht een voorbeeld van multi-disciplinaire samenwerking in de geïntegreerde zorg voor het zieke kind.

Deze kinderarts Ramaekers is bij de academisering van het ziekenhuis in 1983 tot de eerste hoogleraar Kindergeneeskunde in Maastricht benoemd en was dus mijn voorganger toen ik in 1987 besloot het ambt van gewoon hoogleraar Kindergeneeskunde aan de Rijksuniversiteit Limburg te aanvaarden.

In 1991 verhuisde het ziekenhuis, dat toen al 'academisch ziekenhuis Maastricht' heette, naar de huidige locatie en betrok een gloednieuw gebouw in nauwe verbinding met de faculteit der Geneeskunde en Gezondheidswetenschappen. 


\section{De student geneeskunde}

Veel is er de laatste 30 jaar veranderd, zowel voor studenten, als voor assistenten en kinderartsen.

Laten wij eens naar de medische student kijken. Ik heb in de vijftiger jaren gestudeerd aan de Universiteit van Amsterdam en tot het doctoraal examen waren de activiteiten verdeeld tussen Wilhelmina Gasthuis in Amsterdam-West, laboratoria aan de Mauritskade in Oost en Roeterseiland en het Binnengasthuis in het Centrum. Ik moest regelmatig van Amsterdam-West naar Oost of Centrum fietsen en dat deed het gros van de studenten, althans voor colleges in vakken waarin geëxamineerd werd. Voor vakken waarin geen examen werd afgenomen was dit anders. Een interessant college over de geschiedenis van de Geneeskunde mocht zich verheugen in de belangstelling van 10 studenten voor het eerste college en 4 voor het tweede en vervolgens weet ook ik niet meer hoeveel studenten er nog kwamen. De overige colleges werden in het algemeen druk bezocht, waarbij ik wel moet opmerken dat er toen in de horeca nog niet zo'n uitgebreide terras-cultuur was als tegenwoordig en dat verwarmde terrassen nog niet bestonden.

Er waren ook hoogtepunten: de colleges van de internist Borst op zaterdagochtend van 08.15 uur tot 's middags 13.00-14.00 uur waren zo beroemd, dat studenten uit Leiden en Utrecht ervoor naar Amsterdam kwamen, en wij blij waren een ongemakkelijke keukenstoel te bemachtigen waarop je dan urenlang, in een steeds benauwder wordende ruimte, de woorden van de meester opzoog en trachtte op te tekenen.

Of de patientendemonstraties van de chirurg Boerema. De patiënt werd tijdens een inleidend verhaal, veelal met lichtbeelden, in een half-verduisterde zaal binnengeleid, mocht zich achter een scherm van overbodig geachte kledij ontdoen en werd dan in het centrum van een volle collegezaal geplaatst. Vervolgens ging het licht op sterk en werd de afwijking van de patiënt, op welke plek van het lichaam dan ook, aan de studenten vertoond, onder het troostende woord 'geneer $u$ niet, het zijn allemaal jonge dokters'.

Zowel in het recht op privacy van de patiënt als in de onderwijsmethoden is wel wat veranderd in de loop der jaren en het merendeel van die veranderingen kan als een zegen worden beschouwd. In 
Maastricht is het pre-doctorale onderwijs probleemgericht en in blokken van gewoonlijk 6 weken verdeeld. Alle onderwijsruimten zijn gelocaliseerd in 1 modern gebouw. De leerstof wordt per blok ondergebracht in een 15-tal papieren patiënten, casus genoemd, die door de student in leergroepen van 12 man, wekelijks in sessies van 1,5-2 uur worden besproken. De sessies worden bijgewoond door een tutor, die vooral de lijn van de discussie moet bewaken en zich zo min mogelijk inhoudelijk met de kwestie zelf moet bemoeien. Tot voor kort hoefde de tutor niet eens inhoudsdeskundige te zijn. De maatschappelijk werkende was tutor bij de buikklachten en ikzelf ben tutor geweest bij de bespreking van alcohol en andere verslavingen, hoewel daar toch niet mijn grootste deskundigheid ligt. Het 4 uur per week deelnemen aan een tutorgroep is echter niet het enige dat van de Maastrichtse student wordt verwacht. Tijdens de discussie in de tutorgroep worden de problemen van de papieren patiënt geanalyseerd en wordt besproken welke onderwerpen nader bestudeerd moeten worden. Er worden leerdoelen geformuleerd, waaraan in de overige uren van de week wordt gewerkt.

Echte colleges zijn er niet in het Maastrichtse onderwijs, wel zijn er verkapte colleges in de vorm van voordrachten of symposia. In bijna elk blok komen zij voor en ik ben van mening dat het goed is dat van een volledig afwijzen van colleges als vorm van kennisoverdracht is afgestapt. Colleges of lezingen geven toch de mogelijkheid om structuur aan te brengen in de leerstof, de studenten te laten profiteren van persoonlijke ervaringen en hen kennis te laten maken met docenten, van wie er ongetwijfeld, althans toch enige, over didactische kwaliteiten zullen beschikken.

De casus in het blok zijn zorgvuldig geselecteerd en de leerdoelen in grote lijnen vastgesteld door de bij de organisatie van het blok betrokken docenten. Dit lijkt ideaal, maar hier bevindt zich wel een klein addertje in het gras. De deelname aan de organisatie van een onderwijsblok en het vervullen van tutorschappen door leden van een vakgroep wordt per uur beloond door de faculteit in de vorm van het toekennen van formatie. Een vakgroep zal daarom weinig geneigd zijn een eenmaal verworven positie in de organisatie van blokken af te staan. Zo is de kindergeneeskunde er nog niet in geslaagd deel te nemen aan het blok 'Koorts en Infecties', hoewel eenieder het er over eens is dat de kindergeneeskunde hierin thuis hoort. Inwilligen van deze gerechtvaar- 
digde wens van de kindergeneeskunde kost een andere vakgroep echter formatie en geen enkele vakgroep staat graag formatie af. Ieder blok wordt afgesloten met een bloktoets. Behalve de bloktoetsen zijn er $4 \mathrm{x}$ per jaar zogenaamde voortgangstoetsen, waarbij aan alle studenten van alle jaren dezelfde vragen worden voorgelegd. De vragen hebben betrekking op de pre-klinische en klinische geneeskunde, waarbij uiteraard van de Ge-jaars studenten een hogere score wordt verwacht dan van de studenten uit jongere jaren. De vragen worden met zeer veel zorg door een aparte commissie geselecteerd, die daartoe wekelijks bijeenkomt.

De criteria volgens welke de scheidslijn tussen voldoende en onvoldoende bij de verschillende jaargroepen wordt vastgesteld, worden met de grootste zorgvuldigheid bepaald. Wat een vooruitgang vergeleken met de vaak nog mondelinge examens uit mijn studententijd!

De examens waren niet over het studiejaar verdeeld maar gecomprimeerd in juni en september.

Mijn doctoraalexamen Kindergeneeskunde deed ik 's avonds bij Prof. van Creveld thuis. Prof. van Creveld, die zeer klein van postuur was, zat achter zijn buro en de examinandus kreeg een uiterst laag stoeltje aangeboden met de zitting vrijwel op de grond, zodat het examen in de juiste sfeer begon: het slachtoffer moest hoog opzien tegen zijn examinator.

Niet dat van de huidige student niet veel wordt geëist, maar er wordt van alle kanten zorg besteed aan relevantie van de aangeboden leerstof en er wordt gewaakt voor overbelasting. De studiebelasting mag niet meer dan 1600 uur per jaar bedragen voor de gemiddelde student (40 weken van $40 \mathrm{uur}$ ). Er is landelijk een raamplan opgesteld voor de basisarts, waarin gedetailleerd wordt aangegeven welke onderwerpen de basisarts dient te kennen en hoe diepgaand zijn kennis daarover behoort te zijn. Ook de mate waarin hij bepaalde diagnostische en therapeutische vaardigheden dient te beheersen, wordt nauwkeurig omschreven. Dit raamplan, waarin door alle disciplines in de medische opleiding is meegewerkt, zal als leidraad dienen voor de inhoud van het onderwijs in alle Nederlandse medische faculteiten. Hoewel het raamplan nog niet volmaakt is, vormt het toch een aanzienlijke vooruitgang vergeleken bij de periode dat iedere hoogleraar zelf kon uitmaken wat hij van zijn studenten verlangde.

Tot de zegeningen van de Maastrichtse studenten behoort ongetwijfeld 
ook het Skillslab, waar de student medisch-technische ingrepen kan oefenen alvorens hij op de patiënt wordt losgelaten. Een afvaardiging van Duitse hoogleraren kindergeneeskunde, die ons bezocht omdat zij het curriculum Kindergeneeskunde in Duitsland wilden veranderen, was enthousiast over de mogelijkheden in ons skillslab en trouwens ook over de probleemgerichte opzet van de studie in Maastricht. Maar een groot en naar later bleek toch onoverkomelijk probleem was de geringe invloed die de leerstoelhouder kindergeneeskunde op het totale programma had. Bij onze Oosterburen heeft de leerstoelhouder duidelijk een wat groter gezag dan bij ons en dat wilde der Herr Professor niet graag kwijt.

Een belangrijke vooruitgang is het opnemen van keuzestages in het curriculum van de student. In Maastricht zijn voor het keuzeonderwijs 36 weken beschikbaar, dat is $15 \%$ van de totale studietijd. Tijdens de keuzestages moet 12 weken aan wetenschappelijk onderzoek worden besteed. Het heeft mij altijd goed gedaan dat een groot aantal studenten een keuzestage doorbracht bij de kindergeneeskunde met als motivatie dat het een boeiend onderdeel van de geneeskunde is, dat men het in de praktijk veel nodig heeft, en dat in het Maastrichtse reguliere curriculum te weinig aandacht aan de kindergeneeskunde wordt besteed.

Als wij naar de wereld van de student kijken is er dus een hemelsbreed verschil tussen de situatie van vroeger en nu, zowel wat betreft de opbouw van het curriculum, de onderwijsmethoden, als de examinering van de student. Iets om te waarderen.

\section{De assistent.}

Een tweede groep, die in de loop der jaren aanzienlijke zegeningen heeft ondervonden, vormen de assistenten in opleiding tot kinderarts. De opleiding van de basisarts tot kinderarts duurt 5 jaar, waarvan 3-4 jaar in een academische kliniek en 1-2 jaar in een opleidingsafdeling van een algemeen ziekenhuis wordt doorgebracht. De opleiding wordt bewaakt door het Concilium Paediatricum volgens richtlijnen vastgesteld door het Centraal College voor de registratie van specialis- 
ten. Sinds 1991 heeft onze afdeling in het azM een academische opleidingsbevoegdheid voor de kindergeneeskunde. Doordat wij de kleinste academische kinderafdeling in het land zijn, met het geringste aantal bedden, maar ook het kleinste aantal assistenten in opleiding (zeven), kost het bij iedere visitatie weer moeite de visitatoren ervan te overtuigen dat de patientenload voor onze assistenten zeker niet minder is dan in een groot kinderziekenhuis, waar weliswaar meer kinderbedden zijn maar waar het aantal assistenten wel $3-4 \times$ zo groot is als bij ons.

Onze assistenten volgen een niet-academische stage van in principe 1,5 jaar in de kinderafdeling van het St. Maartensgasthuis te Venlo of het de Weverziekenhuis te Heerlen met respectievelijk Dr. The en Drs. Theunissen als niet-academische opleiders.

Door de Stuurgroep Cursorisch Onderwijs van de Nederlandse vereniging voor Kindergeneeskunde is een 5-jaars curriculum met theoretisch onderwijs in de kindergeneeskunde ontwikkeld, dat deels centraal in het land, deels lokaal in de verschillende academische kinderafdelingen wordt gevolgd. Jaarlijks is er een verplichte toets, die vooralsnog alleen ter zelfevaluatie van de assistenten dient, al weet de opleider wel welk resuitaat zijn pupillen hebben behaald, zodat hij een waarderend, bemoedigend of vermanend woord kan laten horen.

De assistent wordt tijdens zijn opleiding gestimuleerd tot deelname aan wetenschappelijk werk. Bij ons heeft dit geleid tot het instellen van een mentoraat, waarbij iedere assistent in opleiding een staflid uitzoekt, die hem op de weg der wetenschap begeleidt (of anders gezegd 'die hem achter de vodden moet zitten').

In mijn opleidingstijd werd ook al gestimuleerd: mijn opleider in het Binnengasthuis te Amsterdam, Prof. van Creveld, sprak alle assistenten aan met 'mijnheer' of 'mevrouw', alleen de gepromoveerden waren 'dokter'. Het was dus 'mijnheer' Kuijten en 'dokter'. Koppe, want Dr. Koppe was 1 jaar eerder in opleiding gekomen en was ook al gepromoveerd. Die frustratie heeft een diep litteken bij mij achtergelaten en een proefschrift werd dan ook voor mij onvermijdelijk.

Vroeger vormden vooral de diensten een zware belasting voor de assistenten. De nachtdiensten en weekenddiensten werden verdeeld over 45 assistenten en hadden plaats na een normale werkdag en werden gevolgd door weer een normale werkdag. Van compensatie had nog 
niemand gehoord. 's Nachts moest je er vaak uit, en soms zag je je bed niet eens. En als je wel in bed kwam, dan was de nacht toch vaak onrustig (het waren kleine kamertjes in het dienstenhuis en naast de kamer van de kindergeneeskunde lag de kamer van de dames van een laboratorium; deze dames hadden nog al eens bezoek en de wanden tussen de kamertjes waren erg dun).

Ook de opvang van acute patiënten door de assistent was totaal anders. Wanneer ik hier in het azM kijk naar de prachtige voor kinderen ingerichte opvangkamer bij de EHBO dan denk ik nog wel eens terug aan de assistententijd in het Binnengasthuis te Amsterdam, gelegen in de buurt van de Wallen. Als assistent moest je daar trouwens ook EHBOdiensten lopen. Ik heb daar menige hechting gelegd in een dronken hoofd, waarvan de eigenaar door 2 stevige broeders in bedwang werd gehouden. Je was daartoe verplicht, ook als a.s. kinderarts, evenals de a.s. dermatoloog en zelfs de a.s. patholoog-anatoom. Kinderen met niet op trauma berustende klachten werden zo snel mogelijk doorgesluisd naar de kinderkliniek. In de kinderkliniek werden acute opnames en aanlopers opgevangen in de badkamer (konden zij meteen in bad als ze opgenomen moesten worden), waar ook de verrijdbare stellages met po's geplaatst waren. Temidden van de po's en een nog dampende badkuip werden er infusen ingebracht en lumbaalpuncties gedaan en dat nog in 1970. De huidige generatie beseft nauwelijks in welke weelde zij nu kunnen werken met disposable materiaal en in keurige ruimtes.

De komst van de algemene maatregel van bestuur, die de werktijden van assistenten in opleiding terugbracht tot gemiddeld 48 uur per week, veroorzaakte een aanzienlijke verandering. Door velen wordt deze als een zegening ervaren, ook al zijn er enige nadelen aan verbonden, waarvan het gebrek aan continuïteit in de patiëntenzorg de grootste is. In onze kliniek hebben wij geprobeerd de negatieve effecten zoveel mogelijk te beperken door de diensten en compensatiedagen in dienstblokken van 3 weken te comprimeren, waarna de assistent in principe 5 weken achtereen beschikbaar is voor de afdeling. Het opstellen van stageprogramma's en dienstroosters voor assistenten en het daarbij zo goed mogelijk bewaken van de continuïteit in de patiëntenzorg met inachtneming van de verplichtingen die de algemene maatregel van bestuur betreffende de werktijden heeft opgelegd, is een heel karwei. Toen de klus weer eens geklaard was voor een bepaalde perio- 
de heb ik mij laten ontvallen, dat ik hoopte dat het kaartenhuis niet in elkaar zou storten door ziekte of zwangerschap van een assistent. Nou, dat heb ik geweten, want een klein beetje uit zijn verband gelicht werd hieruit geconcludeerd dat ik het optreden van zwangerschap van assistenten als een grote ramp zou ervaren! (en dan te bedenken dat ik ze allemaal een groot gezin gun).

$\mathrm{Al}$ naar gelang de ambities of verplichtingen kan de assistent de overige tijd in de week besteden aan ontspanning, wetenschappelijke activiteit, aan sociale bezigheden, verplichtingen ten opzichte van partner of gezin. Met ontzag en waardering heb ik vaak geconstateerd hoeveel sommige assistenten er voor over moeten hebben om een opleiding te combineren met een sociaal leven, waarbij de partner soms ver verwijderd van Maastricht vertoeft.

Wij kennen ook nog de AGNIO, dat is een arts-assistent niet in opleiding, die bij ons hetzelfde werk doet als een assistent die wel in opleiding is. Hij of zij wordt 1-2 jaar aangesteld en werkt hard om alsnog een kans te maken in opleiding te komen, al is het aantal vrijkomende opleidingsplaatsen bij ons te klein om alle AGNIO's een opleiding te kunnen geven. Mijns inziens dient het AGNIO-schap zo snel mogelijk afgeschaft te worden en vervangen te worden door een groter aantal opleidingsplaatsen, een groter aantal stafleden en een andere organisatie van het assistentenwerk. Erg veel assistententijd wordt besteed aan het invullen van briefjes, het maken van telefonische afspraken, administratieve werkzaamheden en andere activiteiten die vaak beter door een doktersassistente of verpleegkundige verricht kunnen worden. U ziet, er is nog genoeg ruimte voor toekomstige zegeningen.

\section{De kinderarts.}

Over het huidige werk van de kinderartsen is wat meer bekend geworden door een recent onderzoek door het NIVEL op verzoek van de Nederlandse Vereniging voor kindergeneeskunde. In ons land waren in mei 1995716 kinderartsen werkzaam. Hiervan werkten er $305(42,6 \%)$ in de 8 academische ziekenhuizen, in totaal $281 \mathrm{fte}$ formatie beslaand. In 101 praktijken in algemene ziekenhuizen waren 355 (49,6\%) kinder- 
artsen werkzaam, samen 314 fte vervullend. 56 kinderartsen (7.8\%) waren niet aan een ziekenhuis verbonden. Van de 101 kinderartsenpraktijken zijn er 4 éénmans-praktijken en 21 tweemanspraktijken. 1/3 van de praktijken bestaat uit 3 kinderartsen. In $43 \%$ van de praktijken zijn meer dan 3 kinderartsen werkzaam. In de algemene praktijk bedraagt het aantal reguliere werkuren (werkuren exclusief avondnacht en weekenddiensten) gemiddeld 52,2 uur per week. Voor de academisch werkenden is dat 56,1 uur per week.

Er moet echter buiten de reguliere werktijd ook nog dienst gedaan worden. Het aantal uren avond- en nachtdienst ligt in de algemene ziekenhuizen tweemaal zo hoog als in de academische ziekenhuizen (28,9 uur per week versus 13,9 per week per fte). Ook het aantal uren weekenddienst per maand is in de algemene praktijk tweemaal zo hoog als bij de academisch werkende kinderartsen ( 90.4 uren versus 46,1 uren).

De diensten en het frequente beroep dat tijdens een dienst op de kinderarts wordt gedaan, vormen een groot bestanddeel van de disutility van de werkende kinderartsen.

In een eerder onderzoek was reeds aangetoond dat kinderartsen een anderhalf maal groter aandeel opnamen buiten de normale werktijd hebben dan de gemiddelde andere specialisten. Per avond/nachtdienst is men gemiddeld 2,9 uur aanwezig in het ziekenhuis en wordt men 3,8 maal per dienst telefonisch geconsulteerd. Per weekenddienst wordt de kinderarts in het algemeen $11 \mathrm{x}$ telefonisch benaderd en is men gemiddeld 12.2 uur aanwezig in het ziekenhuis. Is het dan zo verwonderlijk dat jonge kinderartsen, vooral vrouwen met een gezin, een academische aanstelling prefereren boven een plaats in een algemeen ziekenhuis, vooral als dat laatste een praktijk met 3 of minder kinderartsen betreft, ook al is de honorering in de algemene praktijk beter dan in de academische ziekenhuizen? Op dit moment zijn er in ons land $43 \mathrm{fte}$ vacatures voor kinderartsen. Door uitbreiding van de opleidingscapaciteit zal het tekort aan kinderartsen verminderen en hopelijk worden opgeheven, al zal het gunstige effect hiervan pas over enige jaren merkbaar worden.

Over de honorering van de kinderarts wil ik niet spreken. Wie zich laat leiden door economische motieven kiest niet de kindergeneeskunde als specialisme. Doordat in het verleden verrichtingen overmatig werden gehonoreerd en de tijdsbesteding en het denkwerk minder in de waardering werden betrokken, behoorde de kindergeneeskunde tot de 
financieel achtergebleven gebieden en dat is zo gebleven. Gelukkig is het bestuur van de Nederlandse Vereniging voor Kindergeneeskunde zeer actief geworden op het terrein van de werkomstandigheden van de kinderartsen en de bijbehorende honorering. Wat dat betreft hangen nog enige zegeningen in de lucht, al zullen deze in eerste instantie vooral de kinderartsen in de algemene ziekenhuizen betreffen.

Het is hier de gelegenheid om nog eens te benadrukken hoe belangrijk het is een actief verenigingsbestuur te hebben. Zo is het bestuur van de Nederlandse Vereniging voor kindergeneeskunde er in geslaagd om het eerstvolgende Internationale congres Kindergeneeskunde, het grote wereldcongres, in 1998 naar Nederland te halen. Voor de hele kindergeneeskunde in ons land een enorme stimulans om daar goed voor de dag te komen, zowel wat de organisatie betreft, als wat de wetenschappelijke presentaties aangaat.

Ook is de vereniging actief op het terrein van erkenning en registratie van pediatrische subspecialismen. In de afgelopen jaren legden sommige kinderartsen zich toe op een beperkt gebied van de kindergeneeskunde om daarin een grotere deskundigheid te bereiken. Tot de eerste subspecialismen behoorden de neonatologie en de kindercardiologie. In 1964 werd in Nederland in Amsterdam collega de Bruijne tot eerste hoogleraar in de fysiologie en pathologie van de pasgeborene benoemd. Op dit moment is aan iedere nederlandse universiteit binnen de kindergeneeskunde een leerstoel neonatologie ingesteld. Het opkomen van subspecialismen heeft ertoe geleid dat met name in de universiteitsklinieken kinderartsen zich voor een groot deel of geheel aan een subspecialisme wijden.

Tot volledige afscheiding van het moederspecialisme door subspecialismen, zoals dat bij de Interne Geneeskunde heeft plaatsgehad, is het in de kindergeneeskunde gelukkig nooit gekomen. Een officiële erkenning en registratie van de pediatrische subspecialisten vanuit de Nederlandse Vereniging voor kindergeneeskunde is binnenkort te verwachten.

Bij mijn komst in Maastricht in 1988 zijn wij in de staf van de afdeling kindergeneeskunde overeengekomen, dat het uitbouwen van de patiëntenzorg de hoogste prioriteit moest hebben en daartoe zou het reeds aanwezige aantal deelspecialismen moeten worden uitgebreid. 
Dit was nodig zowel om regionaal als toprefentiecentrum te kunnen fungeren en de kinderen die subspecialistische hulp behoeven in de eigen regio te kunnen behandelen, als om aan onze assistenten een volledige opleiding te kunnen bieden. Dit streven werd gesteund door de Raad van Bestuur van het ziekenhuis, die ons bij de realisering zeer ter wille is geweest.

Door de Nederlandse Vereniging voor Kindergeneeskunde wordt veel aandacht besteed aan verbetering van de kwaliteit van de kindergeneeskundige zorg. De commissie Kwaliteit van de Nederlandse Vereniging voor Kindergeneeskunde, onder leiding van collega Kuis, houdt zich expliciet daarmee bezig. Het opstellen van een raamplan kindergeneeskunde, het verrichten van visitaties van niet-opleidingsklinieken, organisatie, accreditatie en certificatie van nascholingsactiviteiten, het opstellen van behandelprotocollen, gebeurt onder auspiciën van deze commissie. Voor een regelmatige verplichte toetsing of herregistratie examens van de kinderartsen is de tijd nog niet rijp. Door menigeen zou dat niet als een zegening worden ervaren.

Een belangrijke vooruitgang voor de deskundigheid van de geboden pediatrische zorg is het ter beschikking komen van een CD-rom om recente literatuur te kunnen raadplegen. In de tijd daarvoor moest je de index van relevante tijdschriften doorzoeken en de nieuwste tijdschriften waren natuurlijk altijd bij de binder. Mijn opleider, Prof. van Creveld, was steeds goed op de hoogte van de literatuurgegevens, maar altijd pas een dag later. $\mathrm{Na}$ jaren werd mij duidelijk hoe dat kwam: alle nieuwe tijdschriften nam hij eerst mee naar huis. Zijn echtgenote typte de samenvattingen over en legde een trefwoordenregister aan, dat bij opkomende vragen werd geraadpleegd. Voorwaar een privé CD-rom. $\mathrm{Ja}$, dat waren andere tijden.

\section{De Kindergeneeskunde.}

De daling van de kindersterfte is aanzienlijk geweest, vooral als men de cijfers op langere termijn bekijkt en dat geldt voor alle leeftijdsgroepen. De perinatale sterfte is gedaald tot 9.1 per 1000 geboorten in 1993, de zuigelingensterfte tot 5.5 per 1000 levendgeborenen in 1994. Hierbij heeft de vooruitgang van de sociale omstandigheden, verbete- 
ring van de voeding, verhoging van het onderwijspeil, meer aandacht voor het individuele kind in het kleiner blijvende gezin, een belangrijke rol gespeeld. Verder heeft ook de kindergeneeskunde geprofiteerd van belangrijke ontwikkelingen in de geneeskunde, om de anwwinsten op het gebied van beeldvormende technieken zoals echografie, CT-scan en magnetic resonance imaging en de geweldige uitbreiding van het arsenaal antibiotica slechts als voorbeeld te noemen. Sterfteciffers zeggen echter niet alles. Regelmatig zullen blijvende handicaps de tol zijn, die voor het in leven blijven moet worden betaald.

Van de zegeningen die de kindergeneeskunde ten deel zijn gevallen, of beter gezegd die door inspiratie en transpiratie zijn verworven, wil ik er slechts enkele noemen, zonder de ambitie te hebben ook maar in de verste verte volledig te zijn.

De bestrijding van infectieziekten met vaccinaties en de uitbreiding van de mogelijkheden tot antibiotische behandeling hebben de sterfte aan deze aandoeningen aanzienlijk teruggebracht maar nog niet volledig uitgebannen, zoals ook niet te verwachten valt. Inentingen gebeuren tegen difterie, kinkhoest, tetanus, kinderverlamming, mazelen, bof en rode hond en sinds kort ook tegen haemophilus influenzae type B. Tuberculose bij kinderen heeft, althans in Maastricht, nog geen opleving te zien gegeven, terwijl wij ook nog niet getroffen zijn door de verwachte toename van aids op de kinderleeftijd.

Toegenomen kennis op het gebied van circulatie, ademhaling, water- en zouthuishouding en de geweldige toename van technische mogelijkheden hebben geleid tot de oprichting en bloei van de intensive care afdelingen, aanvankelijk vooral voor pasgeborenen.

$\mathrm{Nu}$ is de bedreigde neonaat omgeven met zoveel monitors, knoppen, buizen en slangen, dat ik blij ben, dat er neonatologen zijn, die deskundig met deze knoppen weten om te gaan. In ons land zijn 10 centra voor neonatologische intensive care ingesteld, o.a. een bij ons in Maastricht.

De organisatie van de neonatologische intensive care in ons land is een voorbeeld van een geslaagde poging tot centralisatie. Geslaagd mogelijk, omdat alle 8 academische klinieken tot centrum werden verklaard, een goede regionale verdeling werd bereikt en er 
extra financiële middelen ter beschikking werden gesteld krachtens de zogenaamde ex-artikel 18 voorziening. De resultaten van de neonatale intensive care zijn in ons land bestudeerd o.a. in de zogenaamde POPSstudie waarbij 1338 kinderen met een geboortegewicht onder de 1500 gram, geboren in 1983 werden gevolgd. De sterfe was $28 \%$. Na 5 jaar bedroeg het percentage kinderen met ernstige handicaps $6,5 \%$, het percentage met lichte handicaps $8 \%$. Het aantal zwangerschapsweken en het geboortegewicht waarbij het kind nog kans op overleven heeft, kon steeds verder naar beneden bijgesteld worden.

Met name rond de pasgeborene spelen medisch-ethische problemen een belangrijke rol. In het veelbesproken rapport 'Doen of laten ?' dat de Nederlandse Vereniging voor Kindergeneeskunde in 1992 het licht liet zien, wordt de consensus en de dissensus onder de kinderartsen over al dan niet behandelen van pasgeborenen met zeer ernstige afwijkingen en over al dan niet passief of actief levensbeëindigend optreden, uitvoerig en evenwichtig behandeld.

Op het terrein waarop ik jarenlang actief ben geweest, de kindernefrologie, hebben zich ook belangrijke ontwikkelingen voorgedaan.

Chronische nierinsufficientie, waarbij de nieren zozeer in functie tekort schieten, dat nierfunctievervangende behandeling moet worden toegepast is zeldzaam, maar toch worden er jaarlijks gemiddeld zo'n 22 nieuwe patiënten beneden de leeftijd van 15 jaar in ons land in een dialyseprogramma opgenomen in 1 van de 4 pediatrische dialysecentra. Deze zijn gevestigd in Amsterdam, Rotterdam, Utrecht en Nijmegen. Op 1 januari 1995 bevonden zich 46 kinderen in dialyse. Ook bij kinderen bestaat de dialysebehandeling uit twee hoofdvormen: de hemodialyse en de peritoneale dialyse.

De uiteindelijke behandeling zal een niertransplantatie moeten zijn, hetzij van een levende donor, gewoonlijk een van de ouders, of van een overleden donor. In Nederland wordt meer dan $90 \%$ van de transplantaties bij kinderen verricht met een nier van een overledene. Na 3 jaar functioneert $65 \%$ van de post-mortaal getransplanteerde nieren nog goed en $80 \%$ van de nieren van levende donoren. Wegens het grote aantal complicaties wordt in Nederland pas getransplanteerd als het kind 
een gewicht van 10-12 kg heeft bereikt, dus gewoonlijk omstreeks het begin van het tweede levensjaar. Na transplantatie zijn niet alle problemen verdwenen. Levenslang zijn medicijnen nodig om afstotingsreacties tegen te gaan en desondanks komen deze regelmatig voor. Toch is de vooruitgang aanzienlijk, als je bedenkt dat voor 1970 deze kinderen allemaal overleden.

Gelukkig is men er in Nederland van het begin af aan van doordrongen geweest dat de behandeling van kinderen met chronische nierinsufficientie teamwork is en dat in dat team de psycholoog en de maatschappelijk werkende een belangrijke plaats innemen. In een onlangs verschenen proefschrift van mevr. Hulstijn-Dirkmaat worden de psychologische gevolgen van chronische nierinsufficientie en de behandeling daarvan ook voor ouders en het gezin nog eens duidelijk beschreven. Zijn er bij kinderen onder de 5 jaar vooral problemen met eetlust, dieet en medicijnen, bij de oudere kinderen vormen de zorgen over de toekomst de voornaamste bron van stress in de familie. Daarnaast wordt het lange wachten op een donornier door velen als zeer stressvol ervaren.

Aangezien wij in Zuid-Limburg hoogstens 1-2 nieuwe kinderen met een chronische nierinsufficientie per jaar mogen verwachten, leek het mij niet verantwoord daarvoor een vijfde kinderdialyse centrum te starten, mede gezien de kosten die het oprichten van een kinderdialyse-team met zich mee zou brengen. Enkele patiënten uit de regio zijn naar Nijmegen gegaan, andere naar het WKZ in Utrecht, waarmee wij samenwerken wat betreft controles van getransplanteerde patiënten.

Minder spectaculair, maar betrekking hebbend op een veel grotere groep patiënten, zijn de verworvenheden van de nieuwe beeldvormende technieken voor de kindernefrologie geweest. Naast mictiecystografie en isotopenonderzoek, is het vooral de echografie die het mogelijk heeft gemaakt afwijkingen in de urinewegen vroegtijdig op te sporen, soms al voor de geboorte. Hierop kan dan het beleid worden afgestemd, dat er op gericht is blijvende schade in de nieren door stuwing en infectie te voorkomen en daarmee het ontstaan van chronische nierinsufficientie tegen te gaan. Helaas ontbreken er goede gecontroleerde studies over de beste gedragswijze als er eenmaal afwijkingen gevonden zijn. Wanneer moet je ingrijpen als er bij een pasgeborene eenzijdig het nierbekken verwijd blijkt te zijn? Zowel degenen die agres- 
sief ingrijpen voorstaan, als degenen die wat voorzichtiger zijn ingesteld, claimen goede resultaten.

Het belang van uitgebreid onderzoek bij een bewezen urineweginfectie bij een kind is tot eenieder doorgedrongen, teneinde vesicoureterale reflux (het terugstromen van urine vanuit de blaas naar de hogere urinewegen) bijtijds op te sporen. En hoe dan verder? Het tijdperk dat vele meisjes met recidiverende urineweginfecties een blaashalsplastiek ondergingen ligt achter ons. De voor- en tegenstanders van operatieve correctie van matig-ernstige reflux naderen elkaar, vooral nu door multicenter studies gebleken is, dat in zowel conservatief behandelde als in chirurgisch gecorrigeerde reflux het aantal littekens, dat uiteindelijk in de nieren blijkt te zijn ontstaan, elkaar nauwelijks ontloopt.

De techniek rukt steeds verder op en alleen uit goed onderzoek zal blijken of dat altijd een zegen is. Er bestaat een duidelijk verband tussen het optreden van recidiverende urineweginfecties en abnormale vormen van blaasontlediging bij kinderen. Met anamnese en observatie van de mictie kunnen hierin een aantal patronen worden onderscheiden die van invloed zijn op de verdere behandeling, zoals in ons land door van Gool en de Jong is aangetoond. Exacter is het de blaasfunctie vast te leggen met invasief urodynamisch onderzoek, met blaascatheters en electrodes, maar behoort daarom een dergelijk onderzoek tot een routine bij recidiverende urineweginfecties ? De vooruitgang in diagnostische mogelijkheden wordt pas echt een zegen als daaruit conclusies voor de beste behandeling getrokken kunnen worden, gebaseerd op zorgvuldig wetenschappelijk onderzoek.

De toepassing van longfunctieonderzoek bij kinderen en het besef, dat vroegtijdig onderkennen en behandelen van bronchiale hyperreactiviteit bij kinderen met astma permanente schade aan de longen kan voorkomen, is een grote aanwinst op het gebied van de longziekten bij kinderen. Door verbeterde en zeer intensieve behandeling van kinderen met taai-slijm ziekte, waarvoor een regionaal Cystic Fibrosis team is opgericht, bereiken steeds meer kinderen de adolescentie en volwassenheid.

De gastroenterologie kent vele verworvenheden op het gebied van scopiëen en functieonderzoek, enterale en parenterale voeding. Het 
aantal kinderen met ernstige uitdroging door maag-darmstoornissen is erg afgenomen, vergeleken met vroeger. De verbeterde orale behandeling met glucose-zout oplossingen heeft hierop zeker een gunstige invloed gehad. Echte ondervoeding door gebrek aan voedselaanbod wordt nog maar zelden gezien. Wel heb ik nog nooit zo'n 'mooie' rachitis gezien als hier in Maastricht bij een jongetje dat door een alternatieve voedingswijze gespeend was gebleven van extra vitamine $D$.

De kindercardiologie is door het uitbreiden van de echografie en door toename van de mogelijkheden voor cardiochirurgische ingrepen ook bij pasgeborenen en zuigelingen in een stroomversnelling gekomen. Helaas moeten door noodlottige omstandigheden onze kinderhartoperaties in het WKZ te Utrecht worden uitgevoerd.

Het is hier de gelegenheid om dank uit te spreken aan de medewerkers van de afdelingen cardiologie en cardiochirurgie van het WKZ te Utrecht voor de collegiale wijze waarop in deze wordt samengewerkt met onze kindercardiologen.

De behandeling met groeihormoon behoort tot de verworvenheden, die weliswaar geen levens redden, maar die wel geholpen hebben het aantal handicaps te verminderen. Ook de behandeling van diabetes mellitus op de kinderleeftijd is revolutionair veranderd. Weg zijn de restricties van lichamelijke activiteit en de zware dieetvoorschriften. Zij zijn vervangen door bepaling van bloedsuikergehaltes en regulering en toediening van insuline doses zoveel mogelijk thuis door de patiënt zelf. Een goed voorbeeld van toenemende trans-murale zorg. Op het gebied van zegeningen in de kinderendocrinologie moet hier de landelijke screening op congenitale hypothyreoidie genoemd worden, waardoor in ons land bij omstreeks 60 kinderen per jaar snel kan worden ingegrepen en ernstige geestelijke achterstand kan worden voorkomen.

De vroegtijdige ontdekking van stofwisselirigsziekten en van ontwikkelingsstoornissen en de pediatrische inbreng daarbij vragen extra aandacht van de kinderarts. Het stemt tot tevredenheid dat de regionale samenwerking op het gebied van de phenylketonurie goed op gang is gekomen. Het betreft hier een debiliserende stofwisselingsziekte waarop pasgeborenen worden gescreend en waarbij met tijdige dieet- 
therapie ernstige hersenschade kan worden voorkomen. De goede relatie tussen onze kinderafdeling en het laboratorium voor metabole stoornissen is daarbij essentieel.

Niet alleen de intensive care voor pasgeborenen, maar ook die voor grotere kinderen neemt een belangrijke plaats in binnen de kindergeneeskunde. Kinderen met sepsis, luchtwegobstructie, multi-traumatisées, kinderen die een zware operatieve ingreep hebben ondergaan, krijgen hier deskundige behandeling.

Binnen twee maanden wordt het azM de incorporatie van de intensive care voor grotere kinderen op de kinderafdeling een feit. Tot dan toe was de kinderintensive care gastvrij gehuisvest in de algemene intensive care afdeling van het ziekenhuis. Dit kon worden bereikt door de inzet van velen, vooral van de kinderintensivist en het etagemanagement en door de royale medewerking van de Raad van Bestuur.

$\mathrm{Er}$ is een ophaaldienst georganiseerd die een verantwoorde opvang van levensbedreigde kinderen uit de regio mogelijk maakt.

De kinderarts kan, onder meer door zijn kennis van de normale groei en ontwikkeling, belangrijke bijdragen leveren aan de extramurale kinder- en jeugdzorg. Door het aanstellen van een sociaal pediater, helaas nog slechts part-time, heeft de kindergeneeskunde in Maastricht uitstekende contacten met extra-murale instellingen voor jeugdgezondheidszorg in de regio en nationaal.

Op de neonatologen, en een enkele andere subspecialist na, zijn bij ons alle kinderartsen naast hun subspecialisme ook nog werkzaam op het gebied van de algemene pediatrie. Dit vereist extra inspanning en legt bijzondere verplichtingen op tot bijscholing en het bereiken van consensus in diagnostiek en behandeling.

In mijn opsomming van zegeningen heeft $u$ de hemato-oncologie nog gemist. In Nederland wordt per jaar bij omstreeks 270 kinderen onder de 15 jaar de diagnose kanker gesteld. De meest voorkomende vormen zijn leukemieen $(28,5 \%)$, tumoren van het centrale zenuwstelsel $(21,9 \%)$ en lymfomen $(12,8 \%)$. Een aanzienlijke vooruitgang in de behandeling is geboekt door combinaties van chirurgie, radiotherapie en chemotherapie, in steeds agressievere mate. De 5-jaars overleving van kinderen met kanker ligt tussen de $60-70 \%$. Voor kinderen met een 
niertumor is het 5-jaars overlevingspercentage $85 \%$. Niet alleen de levensverwachting is langer, ook de kans op definitieve genezing is toegenomen. De behandeling van kanker is zeer intensief en kan gepaard gaan met veel bijwerkingen, deels van tijdelijke aard, zoals misselijkheid, braken, gewichtsverlies en kaalheid, deels van een meer blijvend karakter zoals groeiachterstand, overgewicht, onvruchtbaarheid. Voor de zegeningen van een effectieve behandeling moet dus wel een prijs worden betaald.

Tijdens mijn opleiding maakte ik voor het eerst kennis met een kind met een acute lymfatische leukemie. De behandeling sloeg aan maar er trad een recidief op, dat opnieuw goed reageerde, doch slechts zeer kort. Toen wij bij het derde recidief opnieuw naar cytostatica wilden grijpen, namen de ouders, tegen ons advies in, de beslissing dat het kind verder lijden bespaard moest blijven. Zij namen het kind mee naar huis, waar het na twee weken vredig ontsliep. Het was toen 1964 en dat ik u dit nu vertel getuigt van de diepe indruk welke dat patientje toen op mij gemaakt heeft. Ook nu nog staan wij herhaaldelijk machteloos en moet er een beslissing genomen worden over al dan niet voortzetten van de behandeling. Nu echter worden deze beslissingen in gezamenlijk overleg tussen ouders en behandelteam en in geëigende gevallen ook samen met de patiënt genomen.

Zeker voor maligniteiten bij kinderen geldt dat geprofiteerd moet worden van de nieuwste ervaringen en ontwikkelingen. De behandeling van zeldzame vormen van kanker op de kinderleeftijd dient dan ook te geschieden in daarvoor toegeruste kinderoncologische centra. In Nederland worden daartoe 4 plaatsen genoemd, en wel in Groningen, Amsterdam, Rotterdam en Nijmegen.

In Maastricht hebben wij ernaar gestreefd een kinderoncoloog aan ons te verbinden, die contact zou moeten onderhouden met een of meerdere van bovengenoemde centra, zodat de kinderen uit onze regio slechts in uitzonderlijke gevallen naar een centrum (toch altijd minstens $200 \mathrm{~km}$ van Maastricht verwijderd), overgeplaatst zouden moeten worden. Helaas is het budget van het azM nog niet toereikend geweest om een dergelijke functionaris aan te stellen. Ondanks de inzet van velen, en met name mag $\mathrm{ik}$ hier dank betuigen aan de heer Deemers, is het nog niet gelukt een kinderoncoloog aan te stellen met financiering uit externe middelen. 
Wel prijzen wij ons gelukkig met de regelmatige komst van Prof. Vôte uit Amsterdam die hier patientjes controleert en met wie wij kunnen overleggen over patiënten, die daardoor vaak een reis naar of behandeling in Amsterdam bespaard blijft. Ook bij deze patiënten is het zo dat het probleem niet is oplost met een adequate behandeling alleen, maar dat een langdurige begeleiding, zowel medisch als psycho-sociaal, noodzakelijk is.

Elke kinderarts kan op zijn eigen terrein nog andere voorbeelden noemen van de vooruitgang in diagnostiek en behandeling, die een zegen zijn. Zo heb ik nog niet eens gerept over de mogelijkheden van transplantatie van beenmerg, lever, longen en hart, die als hoogstandjes in een multi-disciplinaire behandeling van het zieke kind genoemd kunnen worden. De toekomst heeft nog veel meer in petto.

De snelle groei van de kennis betreffende erfelijke afwijkingen betekent een revolutionaire ontwikkeling voor preventie, diagnostiek en mogelijk behandeling van erfelijke afwijkingen. Door onze voortreffelijke connecties met de afdeling Klinische Genetica zullen wij dit van nabij kunnen meemaken. De daarbij optredende ethische problemen zullen landelijk en internationaal tot felle discussies leiden. Want, zoals op zoveel terreinen, kunnen de zegeningen van de vooruitgang ook hier misbruikt worden. Wanneer prenataal onderzoek leidt tot een ongebreidelde toename van het aantal abortus provocatus omdat de eigenschappen van de vrucht de ouders niet aanstaan, dan is er sprake van een ernstige misstand en verkeert een zegen in een vloek. Bij deze en aanverwante problematiek is mijns inziens de inbreng van de ouders wel zeer belangrijk maar niet de doorslaggevende factor. De confrontatie met een kind met afwijkingen brengt ouders in een soort shocktoestand, waarin zij geholpen en gesteund moeten worden, maar die wel hun oordeelsvorming beïnloedt, zeker in een tijd waarin wij vinden dat alles volmaakt moet zijn.

De kinderarts staat op de bres voor het kind, ook het gehandicapte. Daardoor hebben vele kinderartsen het moeilijk bij de beslissing 'Doen of Laten' en waar zij voor ieder kind individueel de grens moeten leggen.

Omdat men heeft ingezien dat niet alles overal kan, worden veel pogingen in het werk gesteld om te komen tot centralisatie van 
dure of extra voorzieningen vragende activiteiten. Ook de leerstoelhouders kindergeneeskunde zijn daar actief mee bezig. Ik noemde reeds de regionalisatie en centralisatie van neonatale intensive care, van de kinderoncologie van kinderdialysecentra. Pogingen tot centralisatie van b.v. kinderhartchirurgie en kinderneurochirurgie worden ondernomen. De grootste voorstanders van centralisatie worden gevonden in klinieken die verwachten er niet slechter van te worden. Ik kan mij geen voorstander van centralisatie voor de geest halen, die een bepaalde activiteit wilde afstaan. Vooral de kinderafdeling in Maastricht is in deze kwetsbaar, doordat zij de kleinste academische afdeling van het land is en er na centralisatie wel eens heel weinig zou kunnen overblijven. Concentreren op de eigen Euregio is uitstekend maar mag er niet toe leiden dat wij in de verdere verdeling van de Nederlandse koek niet meer meedoen. Het niet toewijzen aan Maastricht van de ECMO als project in de ontwikkelingsgeneeskunde, terwijl er hier ruime ervaring aanwezig is, doet niet veel goeds vermoeden. (Of is onze lobby in Den Haag onvoldoende ?). In plaats van 'centralisatie' klinkt mij trouwens 'taakverdeling' tussen academische kinderafdelingen veel beter in de oren.

\section{Onderzoek.}

Wetenschappelijk onderzoek is een essentieel onderdeel van het werk van de academisch werkzame kinderarts. Uit de reeds eerder genoemde NIVEL enquête blijkt, dat de gemiddelde academisch werkzame kinderarts 10,6 uur/week aan onderzoek besteedt (dit is ongeveer $20 \%$ van zijn werktijd). De meeste resultaten zullen geboekt worden wanneer het onderzoek plaatsheeft in onderzoeksgroepen en tot één van de zwaartepunten van de faculteit of academisch ziekenhuis behoort. Het is beter de gezamenlijke energie te concentreren op één bepaald aspect van één vraagstelling, zodat voldoende diepgang in het onderzoek bereikt kan worden, dan de aandacht te verdelen over een groot aantal verschillende projecten. Daarbij is het wenselijk, dat ook landelijk de kindergeneeskundige inbreng in de verschillende zwaartepunten en onderzoeksscholen als "kindergeneeskunde" herkenbaar blijft. Onze kinderafdeling levert bijdragen aan het zwaartepunt Perinatologie binnen het thema Groei en Ontwikkeling en aan het zwaartepunt Voeding in het kader van de onderzoeksschool Nutrim. 
De kliniek, de observatie en interpretatie van verschijnselen bij het zieke kind, blijft nog steeds een van de pijlers waarop de kindergeneeskunde rust, en die wij niet mogen vergeten aan onze studenten en assistenten te onderwijzen. Met een glimlach bedenk $\mathrm{ik}$, dat een van de ontdekkingen van de laatste jaren, die menige zuigeling het leven heeft gered en veel leed in jonge gezinnen heeft voorkomen, niet afkomstig is uit een zwaar gesubsidieerd onderzoek, niet uit experimenten met muizen, ratten, varkens of lammeren maar het gevolg is geweest van goede observatie en interpretatie door een eenvoudig, bescheiden kinderarts. Ik doel hierbij op het verband tussen wiegedood en de buikligging van de zuigeling door Prof. de Jonge van de VU. Nadat op de gevaren van de buikligging was gewezen en deze vervolgens werd ontraden, is de incidentie van wiegedood in het eerste levensjaar gedaald van 1,2 per 1000 levendgeborenen in 1986 tot 0,3 in 1994 . Dit wil zeggen: alleen al in Nederland sterven er jaarlijks 170 kinderen minder aan wiegedood. Zoals bij vele ontdekkingen gebeurt, is ook hier de onderzoeker allereerst verguist, mede ook vanwege een minder gelukkige wijze van presentatie; maar niet lang geleden is hij volledig in ere hersteld en heeft hij de erkenning gekregen, die hem toekomt.

Voor menig klinisch onderzoek zal de eigen populatie onvoldoende zijn om statistisch significante resultaten te kunnen bereiken. Men is dan aangewezen op multi-center onderzoek, dat naast een goede organisatie ook een consensus in diagnostiek en behandeling vereist. Een dergelijk onderzoek, gestart in 1966 door Henri Barnett betreffende de behandeling van kinderen met een nefrotisch syndroom, is een standaard onderzoek op het terrein van de kindergeneeskunde geweest en de uitkomsten daarvan dienen nog steeds als referentiekader voor verder onderzoek en behandelschema's.

Ook in ons land zijn multicenter-onderzoeken op gang gekomen. Ik noem slechts de behandeling met groeihormoon bij diverse aandoeningen, de behandeling van acute lymfatische leukemie en het onderzoek bij kinderen met een laag geboortegewicht. Maar er zijn er veel meer, veelal gesteund of soms zelf geinitieerd door de farmaceutisch industrie. Naast van fundamenteel onderzoek, vooral op het gebied van de moleculaire biologie, de genetica en de immunologie, valt voor het dagelijks beleid in de kliniek veel te verwachten van multi-center onderzoek en van epidemiologisch onderzoek. 


\section{De patiëntenzorg.}

Ook de patiëntenzorg zelf heeft aanzienlijke veranderingen ondergaan. Het besef, dat vooral het zieke kind behoefte heeft aan vertrouwde personen om zich heen, heeft geleid tot uitgebreide ouderparticipatie in de klinische zorg, met rooming-in als consequentie. Toch ligt de tijd waarin ook op de kinderafdeling tweemaal per dag een bezoekuur was, waarbij broertjes en zusjes niet op de afdeling mochten komen, nog niet zo ver achter ons. Jammergenoeg was de behoefte aan rooming-in nog niet ver genoeg doorgedrongen bij de bouw van het nieuwe azM om de daartoe noodzakelijke voorzieningen te treffen. Maar met wat improvisatie en goede wil kan veel worden bereikt en dat is op onze kinderafdeling gebleken.

Door de medewerking en financiële bijdragen van velen, ziet het er naar uit dat eind 1996 een Ronald McDonaldhuis in de nabijheid van het academisch ziekenhuis verwezenlijkt kan worden. Onder de voortvarende leiding van mevr. Barones van Voorst tot Voorst is daartoe in Maastricht een stichting in het leven geroepen. Ouders en eventueel broertjes en zusjes van hier verpleegde kinderen kunnen dan ver van hun huis, maar dicht bij het zieke kind in een huiselijke omgeving verblijven. Het geeft voldoening te zien hoeveel mensen bereid zijn zich voor een dergelijk doel in te zetten.

Het merendeel van de ouders slaagt er in om in samenwerking met verpleging en spelleiding te komen tot een harmonie in de verzorging van het zieke kind. De spelleiding neemt een zeer belangrijke plaats in binnen de kinderafdeling. Niet alleen door dagindelingen te maken voor de kinderen, ze actief bezig te laten zijn en af te leiden van minder leuke ervaringen, maar ook door kinderen en ouders voor te lichten wat er bij bepaalde onderzoeken en behandelingen precies gaat gebeuren en door hen zo mogelijk bij ingrepen en onderzoeken te begeleiden.

Met steun van particulieren en de Raad van Bestuur is het met medewerking van vrijwilligers mogelijk geworden om kinderen zelf TVprogramma's te laten maken, te laten opnemen en te laten uitzenden via de ziekenhuis TV. Dit is een bezigheid waarbij de kinderen totaal ver- 
geten dat zij in een ziekenhuis verblijven, en waarvoor zij hun ontslag eigenlijk best een nachtje willen uitstellen, of waarvoor zij zelfs willen terugkomen als zij al ontslagen zijn.

Ook de patiëntgerichte verpleging heeft een belangrijke verbetering betekend. Hieronder wordt verstaan dat alle handelingen rondom een bepaalde patiënt zoveel mogelijk door eenzelfde verpleegkundige worden verricht en dat er niet één verpleegkundigeis, die b.v. temperatuur opneemt bij alle kinderen van de afdeling terwijl een andere alle fruithapjes rondbrengt, zoals vroeger gebruikelijk was.

\section{Geïntegreerde zorg voor het zieke kind.}

In Art. 6 van het handvest Kind en Ziekenhuis van de gelijknamige vereniging staat: 'Kinderen worden in het ziekenhuis gehuisvest en verzorgd, samen met kinderen in dezelfde leeftijd en of ontwikkelingsfase. Kinderen worden niet samen met volwassenen verpleegd.

Ook de adolescenten zo tussen 15-18 jaar vinden steeds meer hun weg naar onze afdeling en de daar voor hen aanwezige know-how en voorzieningen. Eigenlijk zou de afdeling geen 'kinderafdeling' moeten heten maar 'Jeugdafdeling' of 'Kinder- en Jeugdcentrum'.

Een van de charmes van onze kinderafdeling is, dat deze zowel de tweede echelons-functie voor Maastricht en omgeving als de derde echelonsfunctie voor Limburg vervult. Hierdoor wordt een gevarieerd ziektepatroon toegankelijk voor de a.s. arts en de a.s. kinderarts. Uit het oogpunt van goede dienstverlening en een optimale zorg is het echter ontoelaatbaar dat soms opnamestops moeten worden afgekondigd omdat ruimtelijke of personele voorzieningen tekort schieten. De patiënt moet dan naar Sittard, Heerlen of Kerkrade gestuurd worden. Het voorkómen van patientenstops stelt extra hoge eisen aan het opnameteam van een afdeling, vooral omdat $75 \%$ van de pediatrische opnames acuut, dus niet gepland is.

Met de incorporatie van de kinderintensive care in de kinderafdeling wordt nog eens extra geaccentueerd, dat de kinderafdeling in het azM een multidisciplinaire afdeling is, waar kinderen van alle specialismen thuis horen. Talrijke andere specialismen, waarbij de kinderchirur- 
gie en de kinderneurologie kwantitatief het grootste zijn, hebben bijgedragen tot de zegeningen van onze kinderafdeling. Mede door hun enthousiasme en de steun van de Raad van Bestuur groeit de kinderafdeling uit tot een regionaal topreferentiecentrum voor kinderen.

Het toenemend besef, dat specialisten moeten samenwerken om tot een geïntegreerde zorg voor het kind te komen, heeft ertoe geleid, dat de kinderarts bij het overgrote deel van de kinderen op de afdeling is betrokken en zo hoort het ook. Kindergeneeskunde is meer dan alleen de interne geneeskunde van het kind. Het is een algemeen specialisme, waarvan elk kind, of het nu met een primair neurologische, chirurgische of orthopedische afwijking wordt opgenomen, moet kunnen profiteren. Verder zijn er multidisciplinaire behandelteams ontstaan voor een aantal ziekten of afwijkingen, waarbij meerdere specialismen hun deskundigheid kunnen inbrengen. Ik noem hier slechts het spina-bifida team, het neurofibromatosis-team, het schisis-team, het cystic fibrosis team, de metabole werkgroep, de werkgroep voor kinderen met hoge luchtwegobstructies, de werkgroep voor cranio-faciale chirurgie. Deze teams vervullen een regionale functie. De meeste teams zijn nog jong en voor enkele geldt dat een verzameling van deskundigen nog geen team is.

Het streven naar verkorting van de ziekenhuishuisopname heeft geleid tot intensivering van diagnostiek en behandeling en tot een aanzienlijke verplaatsing van de werkzaamheden vanuit de kliniek naar de polikliniek en naar de eerste lijn. Wat de polikliniek betreft kan gezegd worden dat de integratie van kinderspecialismen tot één grote kinderpoli nog niet heeft plaatsgehad. Deze door vele specialisten gekoesterde wens stuit nog op ruimtelijke en materiële beperkingen.

Over de samenwerking van de kindergeneeskunde met de huisartsen heerst wederzijdse tevredenheid, zoals bleek uit een onderzoek door het diagnostisch centrum van het azM. Transmurale zorg vanuit de kindergeneeskunde is voorzichtig gestart met de behandeling van kinderen met diabetes of met cystic fibrosis en de begeleiding van kinderen met levensbedreigende afwijkingen in een terminale fase. 


\section{Slotwoord.}

Dames en Heren, met het voorgaande heb ik geprobeerd $U$, de student, de assistent en de kinderarts aan te zetten tot enige reflectie over hetgeen is bereikt. Ik zei het al, van volledigheid kan geen sprake zijn. Het tellen van zegeningen is niet bedoeld als een blijvende activiteit, die het streven naar vooruitgang, zowel in het algemeen als hier in Maastricht, moet intomen. Integendeel: nieuwe ontwikkelingen zullen met veel energie en enthousiasme omgezet moeten worden in toekomstige zegeningen. Af en toe is het echter goed om achterom te kijken en om de zegeningen te waarderen die wij inmiddels deelachtig zijn geworden.

De moeder van een van mijn patiënten zei toen ik haar mededeelde dat ik mijn werkzaamheden hier beëindigde, 'dan gaat u dus nu genieten'. Ik realiseerde mij toen nog eens hoe bevoorrecht ik ben geweest. Niet alleen gá ik genieten maar ik héb mijn hele loopbaan genoten. De geneeskunde in het algemeen en de kindergeneeskunde in het bijzonder is een boeiend werkgebied, dat de werkenden in het veld veel voldoening schenkt. Allen die mij gesteund hebben om mijn werk zo goed mogelijk te doen wil ik hier van harte danken en ik wens hun toe dat zij de vruchten van hun inspanningen mogen plukken.

Rest mij nog een woord van dank te richten tot mijn vrouw.

Lieve Hedy, jij was en bent de spil van ons gezin. Ondanks al je andere verplichtingen was je thuis als de kinderen uit school kwamen en was je mijn steun als ik het wel eens moeilijk had. Ik hoop in de komende tijd goed te maken dat ik je zo vaak alleen moest laten.

Ik wens $u$ allen nog vele zegeningen toe. 


\section{Literatuurlijst.}

\section{J.L.Van den Brande}

Gezocbt : Pedialriscbe bruggenbouwers

Tijdschr.Kindergeneesk. 1993, suppl. 61, 1-7

\section{J.E.W.M.van Dongen-Melman}

On surviving childbood cancer

Acad.Proefscbrifl Rolterdam 1995,ISBN 90-75584016

\section{L.J.Dooren}

Hoe nu verder?

Tijdscbr.Kindergeneesk. 1993, suppl. 61, 31-36

\section{J.D. van Gool, R.de Groot}

Disutility in de werkbelasting van de kinderarts

Mediscb Contact 1991, 46, 331-333

J.D. van Gool, M.A.N.Vijverberg, T.P.V.M. de Jong

Functional daytime incontinence : clinical and urodynamic assessment Scand.J.Urol.Nepbrol. 1992,141 (suppl ), 58-69

\section{P.D. t Hart}

Het zieke kind in goede banden

Uitg.Caterna, Zwolle, 1988

\section{L.Hingstman, J.Harmsen}

Beboefteraming kinderartsen

Conceptrapport NIVEL , sept.1995

\section{G.M.Hulstijn-Dirkmaat}

Cbronic renal failure in Cbildren

Acad.Proefschrift Nijmegen 1995 ISBN 90-9008738-9

International study of Kidney Disease in Children.

The primary nephrolic syndrome in Cbildren

J.Pediatr. 198198 : 561-564

\section{G.A. de Jonge}

Sterfte door wiegedood

Persoonlijke mededeling, nov.1995

\section{G.A. de Jonge , J.Hoogenboezem}

Wiegedood in Nederland in de periode 1980-1993

NTVG 1994, $138: 2133-2137$ 


\section{A.Mulder}

Geboren en getogen

Snoeck-Ducaju \& Zoon, Gent 1995, ISBN 90-53491961

\section{Ned.Ver.Kindergeneeskunde}

Doen of Laten? Grenzen van bet medisch bandelen in de neonatologte

Ned.Ver.Kindergeneesk. 1992 ISBN 90-72254074

\section{Ned.Ver.Kindergeneeskunde}

Kindergeneeskunde in Nederland Anno 1992

Nota Ned.Ver.Kindergeneesk. 1992

\section{A.Okken, M.J.N.C. Keirse}

Het te uroeg geboren kind: moet bet zo uroeg als bet kan?

T.v.Kindergeneesk. 1993, suppl. 61, 7-10

\section{A.Peiper}

Chronik der Kinderbellkunde

Georg Thteme Leipzig, $2 e$ ed. 1955

\section{Renine}

De ontwikkeling van bet nterfunctievervangingsprogramma in Nederland.

Renine , nr 3, 1995

W.J.M.J.Rutten, J.C.J.M. Starmans

St.Annadal 1950-1985

Sticbting Historiscbe Reeks Maastricht, 1987 ISBN 90-70356368

\section{J.M.Smellie, S.P.A.Rigden, N.P.Prescod}

Urinary tract infection : a compartson of four methods of invesigation Arch.Dis.Chtldh. $199572: 247-250$

\section{C.Spreeuwenberg}

Genetisch onderzoek : Zegen of vloek?

Medisch Contact, 1995, 50239

\section{J.E.Strain}

Jacobi address-Pediatrics : Where do we go from bere?

Pediatrics 1995, 95, 924-927

\section{H.K.A.Visser}

Pediatrics in the Netberlands : challenges for today and tomorrow Arch.Dis.Cbildh.1993 69,251-255 